|Araştırma Makalesi / Research Article |

\title{
Bilim Fuarlarına Katılımın Ortaokul Öğrencilerinin Fene Yönelik Tutumlarına Etkisi
}

\section{The Effect of Participation in Science Fairs on Middle School Students' Attitudes towards Science}

\section{Ertan ÇETINKAYA ${ }^{1}$,}

\author{
Anahtar Kelimeler \\ Bilim fuarları \\ Ortaokul öğrencileri \\ тÜBіTAK 4006 \\ Fene yönelik tutum \\ Bilimsel okuryazarlık
}

Keywords
Science fairs
Middle school students
TUBITAK 4006
Attitudes towards
science
Scientific literacy

Başvuru Tarihi/Received 29.09.2019

Kabul Tarihi /Accepted 17.10.2020
Öz

Bu araştırmada bilim fuarlarına katılımın ortaokul öğrencilerinin fene yönelik tutumlarına etkisini incelemek amaçlanmıştır. Tek gruplu ön test son test zayıf deneysel desen olarak tasarlanmıştır. Araştırma 2017-2018 eğitim-öğretim yılının 2. döneminde Marmara Bölgesi'nde bulunan bir devlet okulunda 12 hafta süre ile TÜBITAK 4006 Bilim Fuarları Destekleme Program kapsamında, kolay ulaşılabilir durum örneklemesi yöntemi ile seçilmiş farklı sınıflarda öğrenim gören 32 ortaokul öğrencisi ile gerçekleştirilmiştir. Araştırmada veri toplama aracı olarak Tosun \& Genç (2015) tarafından Türkçeye uyarlanan Fen Tutum Ölçeği (FTÖ) kullanılmıştır. Bu ölçek bilim fuarı projeleri çalışmalarından önce ve bilim fuarı sunumlarından sonra olmak üzere toplam iki kez uygulanmıştır. Verilerin analizi sonucunda bilim fuarlarına katılım göstermenin öğrencilerin fene yönelik tutumlarını anlamlı bir biçimde geliştirdiği saptanmıştır. Bulgular, araştırmaya katılan öğrencilerin cinsiyetlerinin fene yönelik tutum üzerinde anlamlı bir fark oluşturmadığını ortaya koymuştur. Benzer şekilde sınıf seviyesinin fene yönelik tutumda anlamlı bir değişiklik meydana getirmediği görülmüştür. Buna karşın öğrencilerin sınıf seviyelerinin artış gösterdikçe fene yönelik tutum puanlarında azalmalar meydana geldiği araştırmanın dikkat çeken bulguları arasındadır. Öğrencilerin bilim fuarlarına aktif bir biçimde katılımlarının teşvik edilmesinin ve uygulamalı bir biçimde proje eğitimlerine alınmalarının öğrenme süreçlerine olumlu katkılar sağlayacağı ve fene yönelik tutumlarının olumlu yönde gelişimini sağlayacağı düşünülmektedir.

\section{Abstract}

The aim of this study was to investigate the effect of participation in science fairs on the attitudes of middle school students towards science. The research was designed as one-group pretest-posttest poor experimental design. The research was carried out in the second term of 2017-2018 academic year in the scope of TUBITAK 4006 Science Fair Support Program for 12 weeks in a public school in the Marmara Region with 32 middle school students in different classes selected by the method of convenience sampling method. In this study, the Science Attitude Scale that was adapted to Turkish by Tosun \& Genç (2015) was used. This scale was applied twice, one of them before the application of science fair projects and the other one after the presentations of science fair. As a result of the analysis of the data, it was determined that participation in science fairs significantly improved students' attitudes towards science. The findings revealed that the gender of the students participating in the study did not make a significant difference on attitude towards science. Similarly, it was observed that the level of the class did not make a significant change towards attitude towards science. In spite of that, it is remarkable that the attitudes of the students towards science have decreased as their grade levels increase. It is thought that encouraging students' active participation in science fairs and taking them in project trainings in an applied way will contribute positively to the learning processes and provide a positive development of their attitudes towards science.

\footnotetext{
${ }^{1}$ Sorumlu Yazar, Milli Eğitim Bakanlığı, İstanbul, TÜRKiYE; https://orcid.org/0000-0002-5232-4125
} 



\section{Extended Abstract}

\section{Introduction}

The vision of Science Curriculum (MoNE, 2005; 2013; 2017; 2018) prepared in Turkey was determined to raise science literate individuals. Being a scientifically literate person can be provided with interest in science subjects and developing positive attitudes (Yaşar \& Anagün, 2008). Attitudes towards science can be defined as the situation of showing positive or negative affective features related to science. Positive attitude towards science course; has a positive effect on science achievement (Ahuja, 2017; Alkan, 2006, p.25; Çibir \& Özden, 2017; Dede \& Yaman, 2008; Fidan-Dişikitli, 2011, p.57; Kenar \& Balcı, 2012; Kesamang \& Taiwo, 2002; Şişman, Acat, Aypay \& Karadağ, 2011, p.281), permanent learning (Özbaş, 2016) and the development of cognitive competences (Kaya \& Böyük, 2011). In addition to these variables, it was found that there was a negative correlation between the grade level of the students and their attitudes towards science (Çokadar \& Külçe, 2008; George, 2000; Yıldırım \& KansIz, 2017). For this reason, it is seen that it is important for students to develop positive attitudes about science course at early ages. (Hong, Lin, Wang, Chen \& Yang, 2013). Several studies have reported that traditional approaches are not an effective tool for changing students' attitudes towards courses (Altınok \& Açıkgöz-Ün, 2006; Çelik, Eroğlu \& Selvi, 2012; Gök, Doğan, Doymuş \& Karaçöp, 2009; Sert-Çıbık, 2009). Such experiences that can develop positive attitudes are possible with the active participation of students in the learning process. It is thought that the daily life problems are investigated, the students participate actively, the learning environments where they seek solutions to these problems by using their knowledge and skills can be used as an effective tool for developing positive attitude towards science course. Activities which students can participate actively can be carried out in the school or outside of the school. Science fairs are one of these outdoor learning environments.

Science fairs have a positive effect on attitudes towards science course (Alant, 2010; Czerniak \& Lumpe, 1996; Durmaz, Oguzhan-Dincer \& Osmanoglu, 2017; George, 2003; Ndlovu, 2013; Potvin \& Hasni, 2014). However, it was also stated that some science fairs were organized in the form of competitions, that this situation was found competitive by some students and also increased anxiety (Schmidt, 2014; Yaşar \& Baker, 2003). From this point of view, science fairs should be organized in a non-competitive way and should be seen as an opportunity for learning. Lack of study on the impact of science fair practices on students' interest in science is taking attention (Dionne et al, 2012; Finnerty, 2013). In recent years it is seen that the limited research about science fairs which became widespread with the support of The Scientific and Technological Research Council of Turkey (STRCT). Exposing the effects of science fairs on the science course and sharing the future practitioners with the results are thought to have an incentive effect on such initiatives. The aim of this study was to investigate the effect of science fair practices on the attitudes of middle school students towards science.

\section{Method}

The research was designed as one-group pretest-posttest poor experimental design (Fraenkel, Wallen \& Hyun, 2012, p.269). The research was carried out in the second term of 2017-2018 academic year in the scope of TUBITAK 4006 Science Fair Support Program for 12 weeks in a public school in the Marmara Region with 32 middle school students ( 5 male, 27 female). Twenty-seven students are in the $6^{\text {th }}$ grade, two of them are in the $7^{\text {th }}$ grade and three of them are in the $8^{\text {th }}$ grade. In the selection of the study group, convenience-sampling method was used. In this study, the Science Attitude Scale that was developed by Wang \& Berlin (2010) and adapted to Turkish by Tosun \& Genç (2015) was used. The scale consisted of 26 items in five-point Likert type and the reliability coefficient was calculated as 0.916 . Firstly, data collection tools were applied to the students. Then, students were asked to create a project idea for a problem they had encountered and wondered in daily life. In the process; steps such as selection of data collection and measurement tools, recording, analyzing, reporting of collected data and presentation of projects were decided. The projects were conducted by the students and the counselor teachers guided the students in the process. Most of the projects carried out within the scope of the science fair are in the field of science. Majority of science projects consist of studies that are designed as controlled experiments and aim to test the effect of a variable on a situation. The science fair was held in the schoolyard for one day. The students presented their research to each visitor group. Then, the Science Attitude Scale (SAS) was applied to the students and the science fair studies were terminated. The analysis of the data obtained during the research process was performed using SPSS 24.0 package program. For the analysis, the normality assumption of the collected data was tested first. The data showed a normal distribution and the data were analyzed using the paired sample t-test. The results obtained in the analysis of the data were interpreted as $p=.05$ significance level.

\section{Results}

The data were analyzed by the paired sample t-test to examine the effect of science fairs on the attitude of middle school students towards science. Analysis results show that participation in science fairs creates a significant change on the attitudes of middle school students towards science $\left(t_{(31)}=-2.427 ; p=.021<.05\right)$. Independent sample $t$-test analysis was conducted in order to determine whether the gender of middle school students participating in the science fair had a significant difference in their attitudes towards science. The attitude scores of the male and female students before the application $\left(t_{(30)}=-625, p=.536>.05\right)$ and after the research $\left(t_{(30)}=.048 ; p=.966>.05\right)$ shows no significant difference. One-way ANOVA analysis was performed in order to determine the effect of class levels of students attending science fairs on attitude scores. After the analysis, it was found that the grade level did not make a significant difference on the science attitude scores before $\left(F_{(2-29)}=.388\right.$; $\mathrm{p}=.682>.05)$ and after $\left(\mathrm{F}_{(2-29)}=1.047 ; \mathrm{p}=.364>.05\right)$ the science fair.

\section{Discussion}

The findings of this study show that participation in science fair has a significant effect on the attitudes of middle school students towards science lesson. Several studies in the literature (Alant, 2010; Durmaz, Oğuzhan-Dinçer \& Osmanoğlu, 2017; Ndlovu, 2013) support the findings of the present study, which show that attending science fairs positively affect attitudes towards science course. The literature draws attention to the importance of developing positive attitudes towards the science in early ages (Hong, Lin, Wang, Chen \& Yang, 2013). It is stated that students' attitudes and interests towards science developed before 14 (Osborne \& Dillon, 2008). There is a negative correlation between the students' grades and ages and their attitudes towards science course (Francis \& Greer, 1999; Çokadar \& Külçe, 2006). When the findings of this research are examined, it is seen that the attitudes towards science have decreased as the class level increases. In the study, it was found that the gender of the students participating the science fair did not make a significant difference on the attitude points towards the science course. 
In the literature, there are several studies showing that the gender of the students is not a variable that make a significant difference on the science attitude scores (Can \& Dikmentepe, 2015; Kaya \& Böyük, 2011; Yıldırım \& Kansız, 2017; Yıldırım, Şekercioğlu \& Yıldııır, 2018).

Considering that participation in science fairs has a positive effect on students' attitude towards science, it is seen that science fairs should be become prevalent. In this way, a step will be achieved in order to reach the scientific literacy vision, which is the primary objective of science education. It is thought that the repetition of the research with a more balanced group and exposing the reasons behind the opinions of the students towards the science will contribute to the field.

\section{GiRiş}

Bilginin çok hızlı dolaşıma girdiği günümüzde bilimsel bilgiyi bilimsel olmayandan ayırabilen, temel bilimsel becerilere sahip olan nesillerin yetiştirilmesine ihtiyaç vardır. Türkiye'de hazırlanan Fen Bilimleri Dersi Öğretim Programlarının (MEB, 2005; 2013; 2017; 2018) vizyonu da fen okuryazarı bireyler yetiştirmek olarak belirlenmiştir. Fen Bilimleri Dersi Öğretim programının belirlediği hedeflere ulaşmak bilişsel ve duyuşsal alan becerilerinin bir bütün olarak geliştirilmesini gerektirmektedir. Fen eğitimin amaçlarından biri, öğrenenlerin bilişsel alanda gelişmelerinin yanında duyuşsal alanlarda da gelişmesini sağlamaktır (Çakır, Şahin \& Şahin, 2000; Bilgin \& Karaduman, 2005). Fen dersine yönelik tutum da öğrencilerde duyuşsal alanda olumlu yönde geliştirilmesi beklenen becerilerin başında gelmektedir. Bireylerin fen okuryazarı olması, fen konularına ilgi duymaları ve olumlu tutum geliştirmeleri ile sağlanabilir (Yaşar \& Anagün, 2008).

Tutum; bir kişi, nesne ya da konu hakkında genel ve kalıcı olumlu ya da olumsuz bir duygu olarak tanımlanmaktadır (Koballa \& Glynn, 2007, s.78). Diğer yandan tutum, bir derse ya da konuya karşı olumlu veya olumsuz düşünceler besleyerek ve o dersi severek olumlu duyuşsal özellikler gösterme veya o dersi sevmeyerek olumsuz duyuşsal özellikler gösterme hali olarak da tanımlanmaktadır (Kahyaoğlu \& Yangın, 2007). Buradan hareketle fene yönelik tutum kısaca öğrencilerin fen dersine ilişkin olumlu veya olumsuz duyuşsal özellikler gösterme hali şeklinde tanımlanabilir. Fen dersine yönelik tutumu etkileyen değişkenleri açığa çıkarmak öğretim sürecini öğrencinin gözünden görmeye yardımcı olabilir. Aynı zamanda bu sürecin olumlu veya olumsuz yönde etkilediği durumların bilinmesine katkıda bulunabileceği düşünülmektedir. Bu durum bir öğretim süreci tasarlayacak kişilerin olumlu girişimlerin yanı sıra öğretim sürecinin kalitesini düşüren etkenlerin de farkında olmasına yardımcı olur. Literatür incelendiğinde öğrencilerin fene yönelik tutumlarının etkilendiği birden fazla değişken olduğu dikkat çekmektedir. Fen dersine yönelik olumlu tutum; fen başarısına (Ahuja, 2017; Alkan, 2006, s.25; Çibir \& Özden, 2017; Dede \& Yaman, 2008; Fidan-Dişikitli, 2011, s.57; Kenar \& Balcı, 2012; Kesamang \& Taiwo, 2002; Şişman, Acat, Aypay \& Karadağ, 2011, s.281), kalıcı öğrenmeye (Özbaş, 2016), bilişsel yeterliklerin gelişmesine (Kaya \& Böyük, 2011) olumlu yönde etki yapmaktadır. Bu değişkenlerin yanında öğrencilerin öğrenim gördükleri sınıf seviyesi ile fen dersine ilişkin tutumları arasında negatif korelasyon bulunduğu ortaya konulmuştur. (Çokadar \& Külçe, 2008; George, 2000; Yıldırım \& Kansız, 2017). Bu nedenle öğrencilerin erken yaşlarda fen dersine ilişkin olumlu tutum geliştirmelerinin önemli olduğu görülmektedir (Hong, Lin, Wang, Chen \& Yang, 2013).

Öğrencilerin fen dersine ilişkin olumlu yönde tutum geliştirmeleri ancak olumlu yaşantılar yoluyla gerçekleşir. Yapılmış çeşitli çalışmalar (Altınok \& Açıkgöz-Ün, 2006; Çelik, Eroğlu \& Selvi, 2012; Gök, Doğan, Doymuş \& Karaçöp, 2009; Sert-Çıbık, 2009) geleneksel yaklaşımların öğrencilerin derse yönelik tutumlarını olumlu yönde değiştirmede etkili bir araç olmadığını rapor etmiştir. Olumlu tutum geliştirebilecek bu tür yaşantılar öğrencinin öğrenme sürecine aktif katılımı ile gerçekleşen öğretim uygulamaları ile mümkündür. Bu nedenle öğrencilerin fen dersine yönelik olumlu tutum geliştirebilmeleri için bilimsel süreçleri kullanabilecekleri ve aktif olabilecekleri öğretim etkinliklerine katılmaları gerekmektedir. Bahsi geçen öğretim etkinlikleri fen dersinin amaçları ile uyum gösterecek şekilde düzenlendiğinde öğrencilerin hem bilgi ve becerilerini aktif bir biçimde kullanmalarını sağlayacağı hem de derse yönelik olumlu tutum oluşturmalarına katkıda bulunacağı düşünülmektedir. Zira fen dersi, öğrencilerin günlük hayatta karşılaştıkları problemlerle başa çıkmalarına ve doğayı anlamalarına yardımcı olan önemli derslerden biridir (Dilek-Eren, KaradenizBayrak \& Benzer, 2015). Fen dersinde edinilen bilgi, beceri ve tutumlar öğrencilerin yaşamlarında karşılaşacakları sorunların üstesinden gelmelerinde önemli bir araç olarak kullanılabilir. Bu nedenle günlük yaşam problemlerinin araştırma konusu yapıldığı, öğrencilerin aktif bir biçimde katılım gösterdikleri, bilgi ve becerilerini kullanarak bu problemlere çözüm aradıkları öğretim ortamlarının fen dersine yönelik olumlu tutum geliştirmede etkili bir araç olarak kullanılabileceği düşünülmektedir. Öğrencilerin aktif katılım gösterebilecekleri aktiviteler okul içinde gerçekleştirilebileceği gibi okul dışı öğrenme ortamlarında da hayata geçirilebilir.

Öğrencilerin doğayla etkileşim içinde, fenin gerçek yaşamla ilişkilerini inceleyerek, disiplinler arası bir yaklaşımla aktif biçimde öğrendikleri çeşitli okul dışı öğrenme ortamları bulunmaktadır. Okul dışı öğrenme ortamlarına müzeler, hayvanat bahçeleri, botanik bahçeleri, planetaryumlar, sanayi kuruluşları, milli parklar ve doğa eğitimleri örnek verilebilir (Laçin-Şimşek, 2011). Bu ortamlar öğrencilerin fen dersine yönelik ilgilerini ve başarılarını arttırmada etkilidir (Dori \& Tal, 2000). Aynı zamanda okul dışı öğrenme ortamları belirli fenomenlere ilişkin bilgi ve farkındalık kazandırmakta, incelenen konu veya uygulanan etkinlikle ilgili tutum değişikliği sağlamakta ve davranış ile düşünme becerilerinde değişikliğe yol açmaktadır (National Research Council, 2009, s.58). Bahsi geçen okul dışı öğrenme ortamlarından biri de bilim fuarlarıdır.

Bilim fuarları, öğrencilerin çalışmalarını arkadaşlarıyla, öğretmenleriyle, velileriyle, bilim insanlarıyla ve toplumdaki diğer insanlarla paylaştıkları ve deneyimleri ile ilgili yorumlarda bulundukları bir ortamdır (Abernathy \& Vineyard, 2001). Bu ortamlar öğrencilerin bilimsel yöntemleri kullanmalarına yardımcı olarak dersin hedeflerine ulaşmalarını sağlamayı (Tortop, 2014), bilim insanlarının çalışma biçimini anlamalarını, derste öğrendikleri teorik bilgilerini uygulayabilecekleri öğrenme alanları oluşturmayı 
ve bilimsel düşünceyi geliştirerek bilimsel yöntem ve araştırmayı kullanmayı öğrenen bireyleri teşvik etmeyi (Camcı, 2008; Korkmaz, 2004) amaçlamaktadır.

Bilim fuarları öğrencilerin araştırma temelli aktivitelerde yer almasını sağlaması, öğrencileri bilimsel araştırmalara güdülemesi, fen öğrenmeyi sağlaması ve fen dersine yönelik tutumlara olumlu etki yapması açısından fen öğretiminde önemli bir yerde konumlandırılabilecek potansiyele sahiptir. Bilim fuarları, öğrencilerin düşüncelerini başkalarına aktardıkları ve özgüven kazandıkları (Maguth \& Yamaguchi, 2010), öğrencilerin bilim insanı gibi davranmalarına katkı sağladığı (Tortop, 2014), öğrencileri araştırma yapmaya teşvik ettiği (Ngcoza, Sewry, Chikunda \& Kahenge, 2016) ve öğrencilerin araştırma soruları ile bu sorulara yönelik çözüm yöntemleri geliştirdikleri ve edinilen sonuçları tartıştıkları (Chen, Lin, Hsu \& Lee, 2011) için öğrenme sürecinde işlevsel bir ortamdır. Ayrıca bilim fuarlarına katılım gösteren öğrencilerin bilimsel içerikleri popülerleştirdiği, böylece bilimsel kariyerleri takip edebilecekleri düşünülmektedir (Dionne, Reis, Trudel, Guillet, Kleine \& Hancianu, 2012). Bilim fuarları öğrencilerde meydana getirdiği bahsi geçen pozitif yönlü değişimlerin yanı sıra fen dersine yönelik tutumlara da olumlu yönde etki etmektedir. Okul dışı öğrenme ortamlarının (Sorge, Newsom \& Hagerty, 2000) ve bilim fuarlarına katılımın (Alant, 2010; Czerniak \& Lumpe, 1996; Durmaz, Oğuzhan-Dinçer \& Osmanoğlu, 2017; George, 2003; Ndlovu, 2013; Potvin \& Hasni, 2014) fen dersine yönelik tutumları olumlu yönde etkilediğini gösteren çeşitli çalışmalar bu durumu desteklemektedir.

Bilim fuarlarına katılımın olumlu çıktılarının yanı sıra alanyazındaki bazı çalışmalarda öğrencilerin tutumuna yönelik herhangi bir etkisinin olmadığı da ortaya konmuştur. Yaşar ve Baker (2003), Finnerty (2013, s.134) ve Jaworski (2013, s.20) yaptıkları çalışmalarda bilim fuarına katılımın öğrencilerin fene yönelik ilgi ve tutumlarında anlamlı bir fark oluşturmadığını rapor etmişlerdir. Ayrıca bazı bilim fuarlarının yarışma biçiminde düzenlendiği, bu durumun bazı öğrenciler tarafından rekabetçi bulunduğu ve kaygıyı arttırdığı (Schmidt, 2014; Yaşar \& Baker, 2003) dile getirilmiştir. Bu çalışmalar bilim fuarlarının düzenlenme biçimlerinin olumsuz çıktılara yol açabileceğini göstermekte ve bu çıktılar nedeniyle çeşitli eleştiriler tartışma konusu yapılabilmektedir. Bilim fuarlarına yöneltilen çeşitli eleştirilere karşın bu tür girişimler her yaş grubu öğrenciler için yararlı uygulamalar olarak kabul edilmektedir (Korkmaz, 2012). Buradan hareketle bilim fuarlarının rekabete dayanmayan, öğrencilerin, öğretmenler, akranlar ve velilerle karşılıklı paylaşımda bulunduğu bir ortam biçiminde düzenlenmesi ve öğrenme için bir fırsat olarak görülmesi gerekliliği öne çıkmaktadır. Bahsi geçen bir düzenleme ile birlikte gerçekleştirilecek bilim fuarlarının, katılım gösterecek öğrencilerin fen dersine yönelik tutumlarını olumlu yönde değiştirebileceği düşünülmektedir.

Türkiye'de bilim fuarları geçmişte çeşitli özel okulların, belediyelerin, sivil toplum kuruluşlarının il ve ilçe milli eğitim müdürlüklerinin himayelerinde genellikle yerel ölçeklerde gerçekleştirilmiştir. Ancak 2012 yılında TÜBiTAK ile MEB arasında imzalanan protokol uyarınca Bilim ve Toplum Daire Başkanlığı'nın Ulusal Destek Programları kapsamında 4006 Bilim Fuarları Destekleme Programı ilan edilmiştir. Bu program ile 5-12. Sınıflarda öğrenim gören öğrencilerin bilimsel araştırmalar yapmaları teşvik edilmiş, bilimsel okuryazarlık kapsamında bilimsel süreç becerilerinin kazandırılması amaçlanmış ve öğrencilere raporlama ve sunum yapma gibi becerilerin kazandırılması ile birlikte rekabetten uzak ve takım çalışması yoluyla proje hazırlama olanaklarının sağlanması amaçlanmıştır. İlan edildiği yıldan itibaren miktarında önemli değişiklikler olmayan bir miktar finansal destek de kurum tarafından proje kapsamında hibe edilmiştir. TÜBITAK ve MEB tarafından yapılan duyurular ile bahsi geçen programa ilan edildiği günden bu yana başvuru ve katılım sayısı artarak daha fazla öğrencinin bu imkândan yararlanması sağlanmıştır.

Fen okuryazarı bireylerin yetiştirilebilmesi için fene ilgi duyan, fen içeriklerinden hoşlanan, fen dersine yönelik motivasyonları üst düzeyde olan öğrenciler yetiştirilmesi gereklidir. Sayılan özellikler bir bakıma fen okuryazarlığı için ön şarttır. Bu özellikler fen öğrenmeyi etkileyen değişkenler içinde de sayılmaktadır. Bu açıdan düşünüldüğünde öğrencilerin fen dersine yönelik tutumlarının belirlenmesi ve bu tutumlarını etkileyen faktörlerin neden-sonuç ilişkisi içinde detaylı bir şekilde incelenmesine ihtiyaç vardır (Kayri, Elkonca, Şevgin \& Ceyhan, 2014). Bunun yanında okul dışı öğrenme ortamlarından biri olan bilim fuarlarının öğrenme süreçleri üzerinde olumlu etkileri olduğu rapor edilmiştir. Buna karşın bilim fuarı uygulamalarının öğrencilerin fene olan ilgilerine etkisine dair çalışma eksikliği göze çarpmaktadır (Dionne vd., 2012; Finnerty, 2013). Ülkemizde son yıllarda TÜBiTAK desteği ile birlikte yaygınlaşan bilim fuarlarına yönelik yapılmış araştırmaların kısıtlı olduğu dikkat çekmektedir. Bu nedenle bu etkinliklerde öğrencilerin tutumlarını ölçecek çalışmalara ihtiyaç olduğu ifade edilmektedir (Durmaz vd., 2017). Bilim fuarlarının fen dersine yönelik etkilerinin açığa çıkarılması ve gelecekteki uygulayıcıları ile sonuçların paylaşılmasının bu tür girişimlere teşvik etkisi yaratabileceği düşünülmektedir. Ayrıca fene yönelik olumlu tutumların bilim fuarlarının hazırlık sürecine yönelik ciddiyeti de arttırabileceği düşünülmektedir. Bu çalışma da alanyazında bahsedilen bilim fuarı ile fene yönelik tutum arasındaki ilişkiyi inceleyen çalışma eksikliğini giderebilecektir. Buradan hareketle bu çalışmada, bilim fuarı uygulamalarının ortaokul öğrencilerinin fen dersine yönelik tutumlarına olan etkisini incelemek amaçlanmıştır. Bu amaç doğrultusunda bu araştırmanın problem cümlesi “Ortaokul öğrencilerinin bilim fuarına katılımlarının fene /fen bilimleri dersine yönelik tutumlarına anlamlı bir etkisi var mıdır? şeklinde oluşturulmuştur. Bunun yanında bu araştırmada aşağıda verilen alt problemlere de cevap aranmıştır:

Ortaokul öğrencilerinin bilim fuarı öncesi ve sonrasında fen dersine yönelik tutumlarında cinsiyet açısından anlamlı bir farklılık var midır?

Ortaokul öğrencilerinin bilim fuarı öncesi ve sonrasında fen dersine yönelik tutumlarında sınıf seviyesi açısından anlamlı bir farklılık var mıdır?

\section{YÖNTEM}

Bu bölümde araştırmanın modeli, çalışma grubu, uygulama, veri toplama aracı, veri analizi başlıklar halinde sunulmuştur. 


\section{Araştırma Modeli ve Çalışma Grubu}

Araştırmada ön-test son-test tek gruplu zayıf deneysel desen kullanılmıştır (Fraenkel, Wallen \& Hyun, 2012, s.269). Araştırma 2017-2018 eğitim-öğretim yılının 2. döneminde Marmara Bölgesi'nde bulunan bir devlet okulunda 12 hafta süre ile TÜBiTAK 4006 Bilim Fuarı kapsamında gerçekleştirilmiştir. Katılımın gönüllülük esasına dayalı olduğu araştırma bahsi geçen okulda farklı sınıf seviyelerinde öğrenim görmekte olan toplam 32 ortaokul öğrencisi ile gerçekleştirilmiştir. Çalışma grubunun seçiminde kolay ulaşılabilir durum örneklemesi kullanılmıştır. Kolay ulaşılabilir örneklem çalışma yapılmaya hazır bir grup bireyi ifade eder (Fraenkel, Wallen \& Hyun, 2012, s.99). Bu yöntemde araştırmacı kendine yakın olan ve erişilmesi kolay olan bir durumu seçer (Yıldırım \& Şimşek, 2018, s.113). Bu çalışmada da araştırmacı öğretmen olarak görev yaptığı okulda öğrenim görmekte olan öğrencilerle araştırmayı yürütmüştür. Aşağıda araştırmaya katılmış olan öğrencilerin sınıf ve cinsiyet bilgileri tablo halinde sunulmuştur:

Tablo 1. Katılımcıların cinsiyet ve sınıf değişkenlerine göre dağılımı

\begin{tabular}{lcccc}
\hline & 6. sınıf & 7. sınıf & 8. sınıf & Toplam \\
\hline Erkek & 4 & - & 1 & 5 \\
Kız & 23 & 2 & 2 & 27 \\
\hline Toplam & 27 & 2 & 3 & 32 \\
\hline
\end{tabular}

Tablo 1. incelendiğinde öğrencilerin büyük çoğunluğunun $(n=27) 6$. sınıfa devam ettikleri anlaşımaktadır. Bu öğrencilerin de yine büyük çoğunluğu kız öğrencilerden $(n=23)$ oluşmaktadır. Erkek öğrenciler $(n=4)$ ise oldukça az sayıdadır. Katılımcılardan 7. sınıfa devam eden öğrencilerin tamamı $(n=2)$ kızdır. Bununla beraber 8. sınıfa devam eden katılımcılardan $(n=3)$, kız öğrenciler $(n=2)$, erkek öğrencilerden ( $n=1)$ sayıca fazladır. Katılımcılar cinsiyet açısından karşılaştırıldığında büyük çoğunluğunun kız ( $n=27)$ olduğu görülürken erkek öğrencilerin $(n=5)$ azınlıkta kaldığı saptanmıştır.

\section{Veri Toplama Aracı}

Araştırmada ölçme aracı olarak Wang \& Berlin (2010) tarafından geliştirilen ve Tosun \& Genç (2015) tarafından Türkçeye uyarlanan Fen Tutum Ölçeği (FTÖ) kullanılmıştır. Öğrencilerin bilim fuarına katılım durumlarının fen bilimleri dersine yönelik tutumlarına etkisi belirlemek amacıyla likert tipi ölçme aracı ön-test ve son-test olarak katılımcılara iki kez uygulanmıştır. İlköğretim öğrencileri için geliştirilen ölçek, beşli likert tipinde 26 madde içermekte olup dil uyarlaması sırasında güvenirlik katsayısı 0.916 olarak hesaplanmıştır. Mevcut araştırmada ölçeğin güvenirlik katsayısı 0.926 olarak belirlenmiştir. İdeal bir ölçeğe ait Cronbach Alfa güvenirlik katsayısının .70'den yüksek olması beklenmektedir (Pallant, 2013, s. 85). Güvenirlik katsayısının hesaplanması sonrasında ortaya çıkan bu değerler ölçeğin yüksek güvenirliğe sahip olduğunun bir göstergesi olarak kabul edilebilir.

\section{Uygulama Süreci}

Bu çalışmada ilk olarak TÜBITAK 4006 Bilim Fuarı düzenlenecek okulda öğrenim gören bütün seviyedeki öğrencilere bilim fuarlarının amaçları ve çıktıları ile ilgili bilgi verilmiştir. Öğrencilerden günlük hayatta karşılaştıkları ve merak ettikleri bir probleme yönelik proje fikri oluşturmaları istenmiştir. Tamamen gönüllülük esasına dayalı olacağı belirtilmiş ve öğrencilerden gelen dönütler öğretmenler tarafından değerlendirilerek TÜBITAK 4006 Bilim Fuarına proje önerileri girilerek başvurular yapılmıştır. Proje başvurusunun onaylanmasının ardından öğrencilerin bir araştırma problemi oluşturma, bu probleme yönelik araştırma süreci tasarlama, araştırma yapma, veri toplama, verileri analiz etme, ortaya çıkan bulguları inceleyerek çıkarımda bulunma ve araştırma raporu oluşturarak projelerini sunma gibi basamakları uygulayabilmeleri amacıyla projelere danışmanlık yapan öğretmenler tarafından ders dışı egzersiz çalışmaları gerçekleştirilmiştir. Egzersiz çalışmaları ile bilim fuarı projelerine daha nitelikli bir biçimde hazırlanılması ve sürece katılım ile fen dersine yönelik tutumda olumlu yönde değişim sağlanması hedeflenmiştir.

Egzersiz çalışmaları proje bütçesinin hibe edilmesi ile başlayan ve bilim fuarının gerçekleştirilmesini takip eden 12 haftalık süreçte haftada iki saat olarak gerçekleştirilmiştir. Katılımcı öğrencilerin egzersiz çalışmaları, okul idaresi tarafından belirlenen sınıf, atölye ve laboratuvarlarda gerçekleştirilmiştir. Egzersiz çalışmalarının ilk haftasında bilim fuarına katılacak olan öğrencilere Fen Tutum Ölçeği (FTÖ) ön-test olarak uygulanmıştır. İlerleyen haftalarda öğrencilerin daha önceden hazırladıkları proje önerileri temel alınarak araştırma süreci danışman öğretmenler rehberliğinde tasarlanmıştır. Süreç içinde izlenilecek yol; veri toplama ve ölçme araçlarının seçimi, toplanan verilerin kayıt altına alınması, analiz edilmesi, raporlanması ve projelerin sunumunun gerçekleştirilme biçimi gibi basamaklara karar verilmiştir. Birden fazla öğrencinin görev aldığı projelerde görev dağılımı belirlenmiş ve öğrencilerin hem ayrı ayrı hem de birlikte yapacakları iş ve işlemler kararlaştırılmıştır. Egzersiz çalışmaları süresince projeler öğrenciler tarafından yürütülmüş, danışman öğretmenler süreç içinde öğrencilere rehberlik yapmıştır. Araştırmacı ise birden fazla projede danışman öğretmen olarak görev alırken aynı zamanda diğer projelerde danışman öğretmen olarak görev alan öğretmenler arasındaki işbirliği ve bilgi akışını sağlamıştır. Ayrıca araştırmacı bilim fuarının gerçekleştirilmesi için gereken resmi yazışmalar, davetiyelerin hazırlanması, sunum alanının belirlenmesi, düzenlenmesi, araştırma ve deneylerde kullanılacak malzemelerin temini ile yazıım ve istatistik konularında sorumluluk almıştır. Aşağıda araştırmanın gerçekleştirildiği süreç tablo halinde sunulmuştur: 
Tablo 2. Bilim fuarı süreci

\begin{tabular}{|c|c|}
\hline Zaman & Yapılan iş ve işlemler \\
\hline \multirow{7}{*}{ Ön hazırlık } & TÜBіTAK 4006 bilim fuarı hakkında öğrencilere ve öğretmenlere bilgi verilmesi \\
\hline & Proje danışmanlığına gönüllü olan öğretmenlerin tespit edilmesi \\
\hline & $\begin{array}{l}\text { Öğrencilerin proje fikirlerinin, ilgili olan alan öğretmeni tarafından değerlendirilmesi ve düzeltilmesi için öğrenciye dönüt } \\
\text { verilmesi }\end{array}$ \\
\hline & TÜBіTAK 4006 başvuru sistemine 5 farklı branştan/alandan 19 proje önerisinin girişinin yapılması \\
\hline & TÜBітAK denetçileri tarafından projelerin uygulanmaya değer bulunması \\
\hline & Okulda 5 farklı branştan 7 danışman öğretmenin ders dışı egzersiz çalışmaları için başvurması \\
\hline & Ders dışı egzersiz çalışmalarının kabulü \\
\hline 1. Hafta & Fen Tutum Ölçeği (FTÖ) ön-test uygulanması \\
\hline 2. Hafta & $\begin{array}{l}\text { Öğrencilerle birlikte sürecin planlanması, araştırma projeleri için veri toplama araçlarının seçimi, tasarım projeleri için } \\
\text { malzeme listesi oluşturulması ve malzeme temini }\end{array}$ \\
\hline 3. Hafta & Verilerin toplanması / Tasarım projelerinin uygulanmaya başlanması \\
\hline 4. Hafta & Verilerin toplanması / Tasarım projelerinin uygulanmaya başlanması \\
\hline 5. Hafta & Verilerin toplanması / Tasarım projelerinin uygulanmaya başlanması \\
\hline 6. Hafta & Verilerin analiz edilmesi / Tasarlanan projelerin eksiklerinin tartışılması ve öneriler \\
\hline 7. Hafta & Verilerin analiz edilmesi / Tasarlanan projelerin eksiklerinin tartışılması ve öneriler \\
\hline 8. Hafta & Araştırma sonuçlarının raporlanması \\
\hline 9. Hafta & Sunum için poster, projelerin duyurulması için afiş hazırlanması \\
\hline 10. Hafta & $\begin{array}{l}\text { Okul içinde proje görünürlüğünü arttırmak için panolara yapılan projelerle ilgili afişler asılması ve gerekli duyuruların ilgili } \\
\text { makamlara yapılması }\end{array}$ \\
\hline 11. Hafta & Bilim fuarının gerçekleştirilmesi \\
\hline 12. Hafta & Fen Tutum Ölçeği (FTÖ) son-test uygulanması ve araştırma raporlarının TÜBiTAK sistemine girilmesi \\
\hline
\end{tabular}

Bilim fuarı kapsamında gerçekleştirilen projelerin büyük çoğunluğunu fen bilimleri alanında yer alan projeler oluşturmaktadır . Fen bilimleri projelerinin önemli bölümü kontrollü deney olarak tasarlanan ve bir değişkenin bir durum üzerindeki etkisini sınamayı amaçlayan çalışmalardan oluşmaktadır. Bunun yanı sıra Matematik, İngilizce, Türkçe, Spor Bilimleri alanlarından da hem araştırma hem de tasarım odaklı alt projeler hazırlanmıştır. Bilim fuarı kapsamında gerçekleştirilen alt projeler, bu projelerin dâhil oldukları proje alanları ve proje içerikleri Tablo 3'te sunulmuştur:

Tablo 3. Bilim fuarında gerçekleştirilen alt projeler

\begin{tabular}{|c|c|c|}
\hline Alan & Proje Adı & Proje İçeriği \\
\hline Fen & Asitli İçeceklerin Kemiklere Etkisi & $\begin{array}{l}\text { Günlük tüketime konu olan ve asit içeriği barındıran (kola, sirke ve süt) } \\
\text { malzemelerin kemiklere etkisini araştırmak }\end{array}$ \\
\hline Fen & Atma Çayın Atığını Gör Bitkiye Faydasını & Farklı miktarlarda çay posasının bitki gelişimine etkisini incelemek \\
\hline Matematik & Çarpan İp & Çarpım tablosunun öğretimi için bir materyal tasarımı \\
\hline Fen & Deney Yapalım Etkili Suyu Bulalım & $\begin{array}{l}\text { Farklı su çeşitlerinin (deniz suyu, arıtılmış su ve musluk suyu) bitki gelişimine } \\
\text { etkisini incelemek }\end{array}$ \\
\hline İngilizce & Devlerin Omzunda Yüksel & $\begin{array}{l}\text { Bilim tarihinde devrimlere imza atmış bilim insanlarının hayatlarının } \\
\text { araştırılması, yabancı dilde sunumu ve rol oynama }\end{array}$ \\
\hline Fen & Doğru Ürünü Seç Balığın Taze Kalsın & $\begin{array}{l}\text { Çeşitli saklama ortamlarının (tuz, pirinç, vakumlanmış saklama poşeti) balıkların } \\
\text { bozulma süresine etkisini incelemek }\end{array}$ \\
\hline Fen & $\begin{array}{l}\text { Hangi Ekmeği Tüketiyoruz, Hangi Ekmeği } \\
\text { Tüketmeliyiz }\end{array}$ & $\begin{array}{l}\text { Tüketilen ekmek çeşitlerinin kronik hastalıklarla ilişkisini incelemek. Bu } \\
\text { araştırma betimsel bir tarama çalışması biçiminde tasarlanmıştır }\end{array}$ \\
\hline Spor & Harekete Geç & $\begin{array}{l}\text { Obezite riski olan öğrencilerin katılımı ile egzersiz süresince çeşitli spor } \\
\text { aktiviteleri ve beslenme önerileri ile sağlıklı yaşam kültürü oluşturma }\end{array}$ \\
\hline Fen & Işığın Gücü & Yapay ve doğal ışık kaynaklarının bitki gelişimi üzerindeki etkisini incelemek \\
\hline Matematik & Matematiği Arkadaşımdan Öğreniyorum & $\begin{array}{l}\text { Online video platformlarını kullanarak matematik dersinde öğretim programının } \\
\text { belirttiği konuların öğrenciler tarafından işlenmesi ve akran öğretimi yoluyla } \\
\text { diğer öğrencilerin yararlandırıması }\end{array}$ \\
\hline Fen & Mayalara Balon & Farklı pH değerine sahip maddelerin fermantasyon hızına etkisini gözlemlemek \\
\hline Fen & Mikrodalga Işın, Kullanmadan Düşün & Mikrodalgaya maruz kalmış suların bitki gelişimine etkisini incelemek \\
\hline
\end{tabular}




\begin{tabular}{lll}
2490 & & \\
\hline Alan & Proje Adı & Proje içeriği \\
\hline Türkçe & Okuyan Okutur & $\begin{array}{l}\text { Velilerin kitap okuma alışkanlıklarını bir tarama çalışması ile ortaya çıkararak, } \\
\text { ögrencilerin akademik başarıları ile kitap okuma alışkanlığı arasındaki ilişkiyi } \\
\text { incelemek }\end{array}$ \\
Fen & Sağlıklı Dişler, Mutlu Gülüşler & $\begin{array}{l}\text { Farklı içerikteki diş macunları ile fırçalamanın yumurta kabuklarına etkisini } \\
\text { incelemek }\end{array}$ \\
Fen & Şiş Balon Şiş & Farklı sıcaklıklardaki ortamların balonların hacimlerine etkisini incelemek \\
Fen & Tabakta Dans & Farklı marka bulaşık deterjanlarının yüzey gerilimine etkisini incelemek \\
Türkçe & Yanlışı Fark Et, Doğruyu Öğren & Yazım ve imla yanlışlarını öğrenme, tespit etme ve akranlara öğretmek \\
Fen & Yumurtamatik & Haşlanma sürelerinin yumurta kıvamlarına etkisini incelemek \\
Fen & Yumurtanın Kabuğu, Zeytinin Çekirdeği & Organik gübrelerin bitki gelişimine etkisini incelemek
\end{tabular}

Bilim fuarı egzersiz çalışmalarının sonunda bir günlük uygulama ile okul bahçesinde gerçekleştirilmiştir. Bilim fuarına, uygulamanın gerçekleştirildiği okulun öğrencileri ve öğretmenleri, okulun bulunduğu mahalledeki diğer okulların öğrencileri ile öğrencilerin velileri ziyaretçi olarak katılım göstermiştir. Öğrenciler, stantlarına gelen her bir ziyaretçi gruba araştırmalarını sunmuşlardır.

Bilim fuarının uygulanması süresince danışman öğretmenler sorumlu oldukları projelere ait olan stantlarda bulunarak öğrencilere sunumları sırasında rehberlik etmişlerdir.

Bilim fuarının sorunsuz bir biçimde tamamlanmasını takiben uygulamaya katılan öğrencilere Fen Tutum Ölçeği (FTÖ) tekrar uygulanmış ve bilim fuarı çalışmaları sonlandırılmıştır. Verilerin toplanmasının ardından veri analizi işlemlerine geçilmiştir.

\section{Veri Analizi}

Araştırma sürecinde elde edilen verilerin analizi SPSS 24.0 paket programı kullanılarak gerçekleştirilmiştir. Veri analizi gerçekleştirilmeden önce Fen Tutum Ölçeğinde bulunan ters maddeler (Madde 1, 2, 7, 8, 9, 10, 13, 14, 15, 18, 20, 22, 24) düzeltilerek yeni değerler atanmıştır. Analiz için ilk olarak toplanan verilerin normallik varsayımı test edilmiştir. Normallik varsayımı için Kolmogorov-Smirnov, Shapiro-Wilk, Ki-kare uygunluk testi ve basıklık-çarpıklık değer karşılaştırması kullanılmaktadır (Kalaycı, 2009, s. 212). Bunun yanında normallik dağılımını test etmek amacıyla verilerin basıklık ve çarpıklık değer aralığı da kullanılmaktadır. Tabachnick ve Fidell (2013) basıklık ve çarpıklık değerlerinin -1.5 ile +1.5 arasında olması durumunda verilerin normal dağıldığında bahsedilebileceğini dile getirmiştir. Normallik varsayımının test edilmesinin ardından verilerin normal dağılım gösterdiği görülmüş ve verilerin analizi için ilişkili örneklem $t$-testi kullanılmıştır. Verilerin analizinde elde edilen bulgular $p=.05$ anlamlılık düzeyinde yorumlanmıştır.

\section{BULGULAR}

Bu bölümde araştırmanın amacı doğrultusunda bilim fuarlarının ortaokul öğrencilerinin fen dersine yönelik tutumuna etkisine ilişkin bulgular sunulmuştur.

\section{Normallik Testine İlişkin Bulgular}

Katılımcılardan elde edilen verilerin normal dağılım gösterip göstermediğini incelemek amacıyla normallik testi uygulanmıştır. Bu araştırmada da basıklık-çarpıklık değer karşılaştırması ve Kolmogorov-Smirnov, Shapiro-Wilk testlerine başvurulmuştur. Yapılan analizler sonucu elde edilen basıklık ve çarpıklık değer aralıkları Tablo 4'te sunulmuştur:

Tablo 4. Normallik varsayımı için basıklık ve çarpıklık değer aralıkları

\begin{tabular}{lcc} 
& Basıklık & Çarpıklık \\
\hline Ön-test & -.844 & .713 \\
Son-test & -.547 & -.832 \\
\hline
\end{tabular}

Tablo 4 incelendiğinde basıklık ve çarpıklık değerlerinin -.844 ile .713 değerleri arasında yer aldığı görülmektedir. Bu değerler Tabachnick ve Fidell (2013) tarafından önerilen -1.5 ile +1.5 aralığında yer aldığından verilerin normal dağılım gösterdiği bulgusuna ulaşılmıştır.

Kolmogorov-Smirnov ve Shapiro-Wilk normallik testlerinden elde edilen bulgular aşağıda Tablo 5'te sunulmuştur: 
Tablo 5. Kolmogorov-Smirnov ve Shapiro-Wilk normallik testi bulguları

\begin{tabular}{lccc|ccc} 
& \multicolumn{3}{c|}{ Kolmogorov-Smirnov(a) } & \multicolumn{3}{c}{ Shapiro-Wilk } \\
\cline { 2 - 7 } & Statistic & $d f$ & $p$ & Statistic & $d f$ & $p$ \\
\hline Ön-test & .105 & 32 & .200 & .952 & 32 & .160 \\
Son-test & .106 & 32 & .200 & .925 & 32 & .058 \\
\hline
\end{tabular}

Tablo 5 incelendiğinde, Kolmogorov-Smirnov ve Shapiro-Wilk normallik testine göre anlamlılık düzeyi .05'ten büyük olduğundan ön-test ve son-test verilerinin normal dağılıma sahip olduğu bulgusuna ulaşılmıştır.

\section{Bilim Fuarlarına Katılımın Ortaokul Öğrencilerinin Fene Yönelik Tutumuna Etkisine İlişkin Bulgular}

Bilim fuarlarına katılımın ortaokul öğrencilerinin fene yönelik tutumuna etkisini incelemek için araştırmanın öncesinde ve sonrasında toplanan veriler normal dağılım gösterdiğinden parametrik olan testlerden ilişkili örneklem $t$-testi ile analiz edilmiştir. Analiz sonucunda açığa çıkan bulgular aşağıda tablo olarak sunulmuştur:

Tablo 6. Fen Tutum Ölçeği (FTÖ) ilişkili örneklem $t$-testi bulguları

\begin{tabular}{lcccccc} 
& $\boldsymbol{N}$ & $\bar{X}$ & $\boldsymbol{s s}$ & $\boldsymbol{d f}$ & $\boldsymbol{t}$ & $\boldsymbol{p}$ \\
\hline Ön-test & 32 & 109.06 & 14.117 & 31 & \multirow{2}{*}{-2.427} & .021 \\
Son-test & 32 & 114.97 & 11.454 & 31 & \\
\hline
\end{tabular}

Tablo 6 incelendiğinde ilişkili örneklem $t$-testine ilişkin bulgular, bilim fuarlarına katılım göstermenin ortaokul öğrencilerinin fene yönelik tutumlarında anlamlı bir değişim oluşturduğunu ortaya koymaktadır $\left(t_{(31)}=-2.427 ; p=.021<.05\right)$. Araştırma deseni tek gruplu olarak tasarlandığı için fene yönelik tutumlarının değişimindeki etkide bilim fuarının rolünü ortaya koymak amacıyla etki büyüklüğü hesaplanmıştır. Etki büyüklüğü örneklemden elde edilen bulguların sıfır hipotezine ilişkin beklentilerden sapma derecesini gösteren istatistiksel bir değerdir (Cohen, 1988). Cohen'e göre (1988) etki değeri .2, .5 ve .8 olmak üzere üç değer halinde sırasıyla küçük, orta ve yüksek etki olarak sınıflandırılabilir. Bu araştırmada ise etki büyüklüğü için kullanılan Cohen d katsayısı 0.46 bulunmuştur. Elde edilen bu bulgulara göre bilim fuarına katılımın, ortaokul öğrencilerin fene yönelik tutumları üzerinde orta düzeyde anlamlı bir farklılık oluşturacak bir değişken olduğu söylenebilir.

\section{Bilim Fuarlarına Katılan Öğrencilerin Cinsiyetinin Öğrencilerin Fene Yönelik Tutumuna Etkisine illişkin Bulgular}

Bilim fuarı uygulamalarına katılan ortaokul öğrencilerinin cinsiyetlerinin, fene yönelik tutumunda bir farklılık oluşturup oluşturmadığını tespit etmek amacıyla bağımsız örneklem $t$-testi analizi gerçekleştirilmiştir. Analiz sonucunda ortaya çıkan bulgular aşağıda tablo halinde sunulmuştur:

Tablo 7. Cinsiyet değişkenine ilişkin Fen Tutum Ölçeği (FTÖ) bağımsız örneklem $t$-testi bulguları

\begin{tabular}{|c|c|c|c|c|c|c|c|}
\hline & Cinsiyet & $N$ & $\overline{\mathrm{X}}$ & ss & $s d$ & $t$ & $p$ \\
\hline \multirow[b]{2}{*}{ Ön-test } & Erkek & 5 & 105.40 & 18.836 & \multirow[b]{2}{*}{30} & \multirow[b]{2}{*}{-.625} & \multirow[b]{2}{*}{.536} \\
\hline & $\mathrm{K} ı \mathrm{z}$ & 27 & 109.74 & 13.415 & & & \\
\hline \multirow[b]{2}{*}{ Son-test } & Erkek & 5 & 115.20 & 12.988 & \multirow[b]{2}{*}{30} & \multirow[b]{2}{*}{.048} & \multirow[b]{2}{*}{.966} \\
\hline & $\mathrm{K} ı \mathrm{z}$ & 27 & 114.93 & 11.422 & & & \\
\hline
\end{tabular}

Tablo 7 incelendiğinde, araştırmadan önce bilim fuarlarına katılacak erkek ve kız öğrencilerin fene yönelik tutum puanları arasında anlamlı bir farklılık saptanmadığı görülmektedir $(t(30)=-625, p=.536>.05)$. Bilim fuarı uygulamalarının gerçekleştirilmesinin ardından ölçülen erkek ve kız öğrencilerin fene yönelik tutum puanları karşılaştırıldığında bu puanlar arasında da anlamlı bir farklılık meydana gelmediği görülmüştür $\left(t_{(30)}=.048 ; p=.966>.05\right)$. Buradan hareketle bilim fuarına katılan öğrencilerin cinsiyetinin öğrencilerin fen dersine yönelik tutumlarında anlamlı bir farklılık yaratacak bir değişken olmadığı söylenebilir. 


\section{Bilim Fuarlarına Katılan Öğrencilerin Sınıf Seviyelerinin Öğrencilerin Fene Yönelik Tutumuna Etkisine i̇lişkin Bulgular}

Bilim fuarı uygulamalarına katılan ortaokul öğrencilerinin öğrenim gördükleri sınıf seviyelerine ilişkin tanılayıcı istatistik analiz bulguları aşağıda tablo halinde sunulmuştur:

Tablo 8. Öğrencilerin tutum puanlarının sınıf seviyelerine göre tanılayıcı istatistik bulguları

\begin{tabular}{|c|c|c|c|c|c|}
\hline \multirow[b]{2}{*}{ Sinıf Seviyesi } & \multirow[b]{2}{*}{$N$} & \multicolumn{2}{|c|}{ Ön-test } & \multicolumn{2}{|c|}{ Son-test } \\
\hline & & $\overline{\mathbf{x}}$ & ss & $\overline{\mathbf{x}}$ & ss \\
\hline 6. sinif & 27 & 109.93 & 14.60 & 116.04 & 11.14 \\
\hline 7. sınıf & 2 & 107.50 & 2.12 & 114.00 & 4.24 \\
\hline 8. sinif & 3 & 102.33 & 15.30 & 106.00 & 16.52 \\
\hline Toplam & 32 & 109.06 & 14.11 & 114.97 & 11.45 \\
\hline
\end{tabular}

Tablo 8'de yer alan ön-test puanları incelendiğinde 6. sınıfta öğrenim gören öğrencilerin fene tutum puanlarının en yüksek olduğu ( $\bar{X}=109.93)$, 7. sınıf öğrencilerinin onları izlediği ( $\bar{X}=107.50)$, fen tutum puanları en düşük olan öğrencilerin 8. sınıfta öğrenim gören öğrenciler olduğu $(\bar{X}=102.33)$ görülmektedir. Son-test puanları incelendiğinde ise benzer biçimde 6 . sınıf öğrencilerinin en yüksek tutum puanına sahip olduğu $(\bar{X}=116.04), 7$. sınıf öğrencilerinin ikinci sırada yer aldığı $(\bar{X}=114.00), 8$. sınıf öğrencilerinin en düşük fen tutum puanına sahip olduğu ( $\bar{X}=106.00)$ tespit edilmiştir.

Öğrencilerin öğrenim gördükleri sınıf seviyelerinin fene yönelik tutumlarında bir farklılık oluşturup oluşturmadığını tespit etmek amacıyla Tek Faktörlü ANOVA analizi gerçekleştirilmiştir. Analiz sonucunda ortaya çıkan bulgular aşağıda tablo halinde sunulmuştur:

Tablo 9. Öğrencilerin sınıf seviyelerine göre tutum puanlarına ait tek faktörlü ANOVA bulguları

\begin{tabular}{|c|c|c|c|c|c|c|c|c|c|c|}
\hline \multirow[b]{2}{*}{ Varyansın Kaynağı } & \multicolumn{5}{|c|}{ Ön-test } & \multicolumn{5}{|c|}{ Son-test } \\
\hline & $\begin{array}{l}\text { Kareler } \\
\text { Toplamı }\end{array}$ & $s d$ & $\begin{array}{c}\text { Kareler } \\
\text { Ortalaması }\end{array}$ & $f$ & $p$ & $\begin{array}{l}\text { Kareler } \\
\text { Toplamı }\end{array}$ & sd & $\begin{array}{c}\text { Kareler } \\
\text { Ortalaması }\end{array}$ & $f$ & $p$ \\
\hline Gruplar arası & 160.86 & 2 & 80.43 & & & 274.01 & 2 & 137.00 & & \\
\hline Gruplar içi & 6017.02 & 29 & 207.48 & .388 & .682 & 3792.96 & 29 & 130.79 & 1.047 & .364 \\
\hline Toplam & 6177.88 & 31 & & & & 4066.97 & 31 & & & \\
\hline
\end{tabular}

Tablo 9'a göre bilim fuarı uygulamaları gerçekleştirilmeden önce araştırmaya katılacak olan öğrencilerin fen tutum puanları incelendiğinde, sınıf seviyesinin fen tutum puanları üzerinde anlamlı bir fark oluşturmadığı görülmektedir $(F(2-29)=.388 ; p=.682>.05)$. Benzer biçimde bilim fuarının gerçekleştirilmesinden sonra bilim fuarına katılan öğrencilerin fen tutum puanları incelendiğinde, sınıf seviyesinin fen tutum puanları üzerinde anlamlı bir fark oluşturmadığı saptanmıştır ( $F(2-29)=1.047 ; p=.364>.05)$. Buradan hareketle bilim fuarına katılan öğrencilerin sınıf seviyelerinin fene yönelik tutumları üzerinde anlamlı bir farklılık oluşturan bir değişken olmadığı söylenebilir.

\section{TARTIŞMA ve SONUÇ}

Fen dersinde öğrencilerin tutumunun nasıl olduğunun bilinmesi ve tutumlarına etki eden faktörlerin belirlenmesi, derste başarıyı arttırmak için ve öğrencilere dersi sevdirmek için alınacak önlemler konusunda büyük öneme sahiptir (Fidan-Dişikitli, 2011, s.2). Buradan hareketle öğrencilerin fen dersine yönelik tutumlarının belirlenmesine ve deneyimledikleri öğrenim ortamlarının bu tutuma etkisinin araştırılmasına ihtiyaç vardır. Bu araştırmanın bulguları, bilim fuarı uygulamalarına katılımın ortaokul öğrencilerinin fen dersine yönelik tutumlarını anlamlı bir biçimde etkilediğini göstermektedir. Literatürde yer alan ve bilim fuarlarına katılımın fen dersine ilişkin tutumu olumlu yönde etkilediğini gösteren çeşitli çalışmalar (Alant, 2010; Durmaz, OğuzhanDinçer \& Osmanoğlu, 2017; Ndlovu, 2013) mevcut çalışmanın ulaştığı bulguları destekler niteliktedir.

Kim ve Kwon (2016) bilim fuarına katılan öğrencilerin fene yönelik tutumlarının olumlu yönde değişim gösterdiğini; bilimsel ilgi, merak ve işbirliği gibi özelliklerinin geliştiğini dile getirmektedir. Ahn ve Park (2009) yaptıkları çalışmada hazırlık çalışmaları da dâhil olmak üzere bilim fuarlarına katılım göstermenin fene yönelik tutumla birlikte araştırma ve sorgulamaya dayalı süreç becerilerini geliştirdiği sonucuna ulaşmışlardır. Benzer biçimde Schmidt ve Kelter (2017) bilim fuarlarına katılımın öğrencilerin fene ya da fenle ilişkili bir kariyere olan ilgilerini arttırdığını ve sunum becerilerini geliştirdiğini ifade etmektedir. Bahsi geçen araştırma sonuçlarının yanı sıra literatürde bilim fuarı uygulamalarının öğrencilerin fene ilişkin tutumlarını olumlu biçimde etkilemediğini raporlayan bazı çalışmalar da mevcuttur.

Jaworski (2013, s. 23-24) bilim fuarlarını ziyaret eden öğrencilerin fene yönelik tutumlarında olumlu yönde değişiklik meydana geldiğini ifade ederken sadece bilim fuarı öncesinde fene ilgisi olan katılımcıların tutumlarının olumlu yönde değiştiğini, diğer 
katılımcıların tutumlarının ya değişmediğini ya da düşüş gösterdiğini ifade etmiştir. Blenis (2000) yarışmacı bir biçimde düzenlenen ve sonunda ödül verilen bilim fuarlarına katılan öğrencilerin, yarışma tabanlı düzenlenmeyen ve gönüllü katılımın olduğu bilim fuarlarına katılan öğrencilere göre daha düşük fen tutumu geliştirdiklerini tespit etmiştir. Buna karşın gruplar arasında fen tutumu açısından anlamlı bir farklılık saptanmamıştır. Finnerty $(2013$, s.178) ise bilim fuarına katılımın öğrencilerin fen dersine yönelik tutumlarında anlamlı bir değişime neden olmadığını, danışman öğretmenlerin bu duruma zaman yetersizliğini sebep olarak gösterdiklerini rapor etmiştir. Bilim fuarlarına yöneltilen eleştirilere karşın bu tür girişimler her yaştan öğrenci grubu için faydalı uygulamalar olarak kabul edilmektedir (Korkmaz, 2012).

Alanyazın, öğrencilerin erken yaşlarda fene yönelik olumlu tutum geliştirmelerinin önemine dikkat çekmektedir (Hong, Lin, Wang, Chen \& Yang, 2013). Zira öğrencilerin fene yönelik tutum ve ilgilerinin 14 yaş ve öncesinde geliştiği ifade edilmektedir (Osborne \& Dillon, 2008). Bireylerin fene yönelik tutumları onların gelecekteki kariyer seçimlerini de etkileyeceğinden dolayı erken yaşlarda fene yönelik tutumlarının olumlu yönde geliştirilmesinin bir gereklilik olduğu düşünülmektedir. Çünkü öğrencilerin sınıf seviyeleri ve yaşları ile fen dersine yönelik tutumları arasında ters korelasyon bulunmaktadır (Francis \& Greer, 1999; Çokadar \& Külçe, 2006). Bu araştırmanın bulguları incelendiğinde de benzer biçimde sınıf seviyesi arttıkça fene yönelik tutum puanlarında düşüşler meydana geldiği dikkat çekmektedir. Bu nedenle öğrencilerin fene yönelik tutumlarını olumlu yönde değiştirecek veya sınıf seviyesi arttıkça fene yönelik tutumlarının olumsuz yönde değişimini engelleyecek uygulamalara yer verilmesinin gerekli olduğu düşünülmektedir.

Araştırmada bilim fuarına katılım gösteren öğrencilerin cinsiyetinin fen dersine yönelik tutum puanları üzerinde anlamlı bir farklılık oluşturmadığı saptanmıştır. Alanyazında da öğrencilerin cinsiyetinin fen tutum puanları üzerinde anlamlı bir fark oluşturmayan bir değişken olduğunu gösteren çeşitli araştırmalar bulunmaktadır (Can \& Dikmentepe, 2015; Kaya \& Böyük, 2011; Yıldırım \& Kansız, 2017; Yıldırım, Şekercioğlu \& Yıldırır, 2018). Farklı sınıf ve eğitim kademelerinde farklı amaçlar için tasarlanan araştırmaların birçoğunda ortaya çıkan bu sonuçlar, mevcut araştırmada elde edilen cinsiyetin fene yönelik tutum üzerinde anlamlı bir farklılık oluşturmadığı bulgusunu desteklemektedir.

Araştırmada sonuç olarak bilim fuarlarında sunulacak bir projede katılımcı olarak yer almanın öğrencilerin fen dersine yönelik tutumlarını anlamlı bir biçimde olumlu yönde etkilediği tespit edilmiştir. Bu sonuç hesaplanan etki büyüklüğü değeri ile de desteklenmiştir. Araştırmanın verilerinden yapılan hesaplamalarla etki büyüklüğünün orta düzeyde olduğu saptanmıştır. Cohen $(1988$, s.26) orta düzeydeki etki düzeyinin çıplak gözle görülebilecek kadar büyük olduğunu ve örnek olarak 14 yaşındaki kızlar ile 18 yaşındaki kızlar arasındaki boy farkına karşılık geldiğini ifade etmiştir. Bunun yanı sıra bilim fuarına katılan kız ve erkek öğrencilerin fen tutum puanları arasında anlamlı bir farklılığın olmadığı görülmüştür. Ayrıca sınıf seviyesi ile fene yönelik tutum arasında negatif yönde bir korelasyon olduğu tespit edilmiştir. Öğrencilerin yaşları ilerledikçe fen dersine yönelik tutum puanlarında azalmalar meydana geldiği saptanmıştır.

Bilim fuarları, öğrencinin günlük yaşam problemlerinin farkında olmasına ve bu problemlerin kaynağı ile çözümüne ilişkin bir merak duymasına birinci dereceden bağlı uygulamalardır. Öğrencinin merak duygusunun göz ardı edildiği örnekler genellikle danışman öğretmenlerin ürünü, öğrencinin sunucusu olduğu projelerin ortaya çıkmasına neden olmaktadır. Böyle bir durum öğrencinin bir bilim insanı gibi düşünmesine ve problemleri bir bilim insanı gibi kavramasına engel olmaktadır. Zira bilim fuarlarının bir amacı da öğrencilerin bilim insanlarının nasıl çalıştıklarını anlamalarını sağlamak, derslerde öğrenmiş oldukları teorik bilgileri uygulama olanağına sahip olmaktır (Young, 2000). Bu süreçte merak duygusu teşvik edilmemiş ya da uygulamaları bizzat gerçekleştirme olanağı bulamamış öğrencilerin fene yönelik tutumlarının ileri düzeyde artış göstermelerini beklemek gerçekçi olmayacaktır.

\section{ÖNERILER}

Araştırma sonucunda öğrencilerin merak duygularının göz önüne alındığında bilim fuarlarına katılımlarının artış gösterdiği ve fen dersine yönelik tutumlarının da anlamlı bir biçimde etkilendiği tespit edilmiştir. Bu nedenle öğrencilerin proje sürecinde aktif olmalarını sağlayabilecek önlemlerin alınması ve gerekli görüldüğü durumlarda bilim fuarlarının hazırlık çalışmalarından önce bir projenin gerçekleştirilme aşamalarının uygulamalı olarak yürütüleceği eğitimlere alınması önerilmektedir.

Bilim fuarlarına katılımın öğrencilerin fene yönelik tutumu olumlu etkilediği düşünüldüğünde bilim fuarı uygulamalarının yaygınlaştırılması önerilmektedir. Bu yolla fen eğitiminin başat hedefi olan bilimsel okuryazarlık vizyonuna ulaşabilmek için bir aşama kaydedilmiş olacaktır.

Mevcut araştırmada bilim fuarına katılım gönüllülük esasına dayalı olduğu için farklı sınıf seviyelerinde araştırmaya katılan öğrenci frekanslarında dengesiz bir durum ortaya çıkmıştır. Bu nedenle araştırmanın sınıf seviyeleri arasında daha dengeli bir dağılım gösteren grupla tekrarlanması önerilmektedir. Bu yolla açığa çıkan sonuçların alana katkı sağlayacağı düşünülmektedir.

Bu çalışma doğası itibari ile deneysel desen ile tasarlandığı için öğrencilerin fen dersine yönelik tutumlarının ve bu tutumlardaki değişimin altında yatan nedenler incelenememiştir. Bahsi geçen gerekçelerin ortaya çıkarılabilmesi ve öğrencilerin fene yönelik görüşlerinin ardında yatan nedenlerin açığa çıkarılması için derinlemesine incelemeye imkân veren araştırmaların yürütülmesi önerilmektedir. Böylece öğrencilerin bilim fuarına katılımlarını etkileyen faktörler açığa çıkarılabilecek ve ayrıca fen dersine yönelik tutumlarının bilim fuarı ile ilişkili boyutları anlaşılabilecektir. Eğitim araştırmacıları ve öğretmenler için fene yönelik tutum ile bilim fuarlarına katılım arasındaki ilişkinin aydınlatılmasının da ayrıca önem taşıyacağı düşünülmektedir. 


\section{KAYNAKÇA}

Abernathy, T. V. \& Vineyard, R. N. (2010). Academic competitions in science: What are the rewards for students? The Clearing House: A Journal of Educational Strategies, Issues and Ideas, 74(5), 269-276. doi: 10.1080/00098650109599206

Ahn, K. \& Park, I. (2017). Effect of participation in science fairs on perception, science related attitudes and science inquiry process skill of elementary school children. Journal of Korean Elemantary Science Education, 28(3), 304-312.

Ahuja, A. (2017). Study of scientific attitude in relation to science achievement scores among secondary school students. Educational Quest: An International Journal of Education and Applied Social Science, 8(1), 9-16. doi: 10.5958/2230-7311.2017.00002.2

Alant, B. P. (2010). "We cross night": Some reflections on the role of the ESKOM Expo for Young Scientists as a means of accommodating disadvantaged learners into the field of science and technology. Perspectives in Education, 28(4), 1-10.

Alkan, A. (2006). ilköğretim öğrencilerinin fen bilgisine karşı tutumları. Yayınlanmamış Yüksek Lisans Tezi. Afyon Kocatepe Üniversitesi Sosyal Bilimler Enstitüsü, Afyonkarahisar.

Altınok, H. \& Açıkgöz-Ün, K. (2006). İşbirlikli ve bireysel kavram haritalamanın fen bilgisi dersine yönelik tutum üzerine etkileri. Hacettepe Üniversitesi Eğitim Fakültesi Dergisi, 30, 21-29.

Bilgin, İ. \& Karaduman, A. (2005). İşbirlikli öğrenmenin 8. sınıf öğrencilerinin fen dersine karşı tutumlarına etkisinin incelenmesi. ilköğretimOnline, 4(2), 32-45.

Blenis, D. S. (2000). The effects of mandatory, competitive science fairs on fifth grade students' attitudes towards science and interests in science. East Lansing, MI: National Center for Research on Teacher Learning.

Camcı, S. (2008). Bilim şenliğine katılan ve katılmayan öğrencilerin bilim ve bilim insanlarına yönelik ilgi ve imajlarının karşılaştırılması. Yayınlanmamış Yüksek Lisans Tezi. Hacettepe Üniversitesi Sosyal Bilimler Enstitüsü, Ankara.

Can, ş. \& Dikmentepe, E. (2015). Ortaokul öğrencilerinin fen ve teknoloji dersi ile fen deneylerine yönelik tutumlarının araştırılması (Muğla ili örneği). Muğla Sıtkı Koçman Üniversitesi Eğitim Fakültesi Dergisi, 2(1), 44-58. doi: 10.21666/mskuefd.50344

Chen, J-J., Lin, H-S., Hsu, Y-S. \& Lee, H. (2011). Data and claim: The refinement of science fair work through argumentation. International Journal of Science Education, Part B: Communication and Public Engagement, 1(2), 147-164. doi: 10.1080/21548455.2011.582707

Cohen, J. (1988). Statistical power analysis for the behaviorial sciences.(Second edition). New York: Lawrence Erlbaum Associates.

Czerniak, C. M. \& Lumpe, A. T. (1996). Predictors of science fair participation using the theory of planned behaviour. School Science and Mathematics, 96(7), 355-361. doi: 10.1111/j.1949-8594.1996.tb15853.x

Çakır, Ö. S., Şahin, B. \& Şahin, T. (2000). Türkiye'de farklı coğrafi bölgelerde bulunan okullardaki öğrencilerin fen bilgisi dersindeki kişisel, bilişsel, duyuşsal ve sosyal açıdan karşılaştırmalı olarak incelenmesi. IV. Fen Bilimleri Eğitimi Kongresi Bildirileri, 6-8 Eylül 2000, Hacettepe Üniversitesi Eğitim Fakültesi, Bildiriler kitabı, (s. 201-205), Ankara.

Çelik, E., Eroğlu, B. \& Selvi, M. (2012). Fen eğitiminde probleme dayalı öğrenme yaklaşımının öğrencilerin akademik başarısı ile fen ve teknoloji dersine yönelik tutumlarına etkisi. Kastamonu Eğitim Dergisi, 20(1), 187-202.

Çibir, A. \& Özden, M. (2017). İlkokul öğrencilerinin fen dersine yönelik tutumları: Kütahya örneği. Eğitim Bilimleri Araştırmaları Dergisi, 7(2), 4561.

Çokadar, H. \& Külçe, C. (2008). Pupils' attitudes towards science: A case of Turkey, World Applied Sciences Journal, 3(1), 102-109.

Dede, Y. \& Yaman, S. (2008). Fen öğrenmeye yönelik motivasyon ölçeği: Geçerlik ve güvenirlik çalışması. Necatibey Eğitim Fakültesi Elektronik Fen ve Matematik Eğitimi Dergisi (EFMED), 2(1), 19-37.

Dilek-Eren, C., Karadeniz-Bayrak, B. \& Benzer, E. (2015). The examination of primary school students' attitudes toward science course and experiments in terms of some variables. Procedia - Social and Behavioral Sciences, 174, 1006-1014. doi: 10.1016/j.sbspro.2015.01.1245

Dionne, L., Reis, G., Trudel, L., Guillet, G., Kleine, L. \& Hancianu, C. (2012). Students' sources of motivation for participating in science fairs: An exploratory study within the Canada-wide science fair 2008. International Journal of Science and Mathematics Education, 10(3), 669693. doi: 10.1007/s10763-011-9318-8

Dori, Y. J. \& Tal. R. T. (2000). Formal and informal collaborative projects: Engaging in industry with environmental awareness. Science Education, 84(1), 95-113. doi: 10.1002/\%28SICI\%291098-237X\%28200001\%2984\%3A1<95\%3A\%3AAID-SCE7>3.0.CO\%3B2-W

Durmaz, H., Oğuzhan-Dinçer, E. \& Osmanoğlu, A. (2017). Bilim şenliğinin öğretmen adaylarının fen öğretimine ve öğrencilerin fene yönelik tutumlarına etkisi. Trakya Üniversitesi Eğitim Fakültesi Dergisi, 7(2), 364-378. doi: 10.24315/trkefd.296520

Fidan-Dişikitli, A. (2011). ilköğretim 7. ve 8. sınıf öğrencilerinin fen ve teknoloji dersine yönelik tutumları ile fen ve teknoloji dersi başarıları arasındaki ilişki. Yayınlanmamış Yüksek Lisans Tezi, Selçuk Üniversitesi Eğitim Bilimleri Enstitüsü, Konya.

Finnerty, V. (2013). Can participation in a school science fair improve middle school students' attitudes toward science and interest in science careers? Unpublished doctoral dissertation, University of Massachusetts Lowell. Massachusetts, USA.

Fraenkel, J. R., Wallen, N. E. \& Hyun, H. H. (2012). How to design and evaluate research in education (8th edition). New York: McGraw Hill.

Francis, L. J. \& Greer, J. E. (1999). Measuring attitude toward science among secondary school students: The affective domain. Research in Science and Technological Education, 17(2), 219-226. doi: 10.1080/0263514990170207

George, R. (2000). Measuring change in students' attitudes toward science over time: An application of latent variable growth modeling. Journal of Science Education and Technology, 9(3), 213-225. doi: 10.1023/A:1009491500456

George, R. (2003). Growth in students' attitudes about the utility of science over the middle and high school years: Evidence from longitudinal study of American youth. Journal of Science Education and Technology, 12(4), 439-448. doi: 10.1023/B:JOST.0000006303.63545.0f

Gök, Ö., Doğan, A., Doymuş, K. \& Karaçöp, A. (2009). İşbirlikli öğrenme yönteminin ilköğretim öğrencilerinin akademik başarılarına ve fene olan tutumlarına etkileri. Gazi Eğitim Fakültesi Dergisi, 29(1), 193-209.

| Kastamonu Eğitim Dergisi, 2020, Vol. 28, No. 6| 
Hong, Z-R., Lin, H-S., Wang, H-H., Chen, H-T. \& Yang, K-K. (2013). Promoting and scaffolding elementary school students' attitudes toward science and argumentation through a science and society intervention. International Journal of Science Education, 35(10), 1625-1648. doi: 10.1080/09500693.2012.734935

Jaworsky, B. A. (2013). The effects of science fairs on students' knowledge of scientific inquiry and interest in science. Unpublished masters thesis, Montana State University, Bozeman, Montana, USA.

Kahyaoğlu, M. \& Yangın, S. (2007). İlköğretim öğretmen adaylarının mesleki öz-yeterliklerine ilişkin görüşleri. Kastamonu Eğitim Dergisi, 15(1), 73-84.

Kalaycı, Ş. (2009). SPSS uygulamalı çok değişkenli istatistik teknikleri (4. Baskı). Ankara: Asil Yayın Dağıtım.

Kaya, H. \& Böyük, U. (2011). İlköğretim II. kademe öğrencilerinin fen ve teknoloji dersine ve fen deneylerine karşı tutumları. TÜBAV Bilim Dergisi, $4(2), 120-130$.

Kayri, M., Elkonca, F., Şevgin, H. \& Ceyhan, G. (2014). Ortaokul öğrencilerinin Fen ve Teknoloji dersine yönelik tutumlarının CHAID analizi ile incelenmesi. Eğitim Bilimleri Araştırma Dergisi, 4(1), 301- 316. doi: 10.12973/jesr.2014.41.15

Kenar, i. \& Balcı, M. (2012). Fen ve teknoloji dersine yönelik tutum ölçeği geliştirme: İlköğretim 4. ve 5. sınıf örneği. Dumlupınar Üniversitesi Sosyal Bilimler Dergisi, 34, 201-210.

Kesamang, M. E. E. \& Taiwo, A. A. (2002). The correlates of the socio-cultural background of Botswana junior secondary school students with their attitudes towards and achievements in science. International Journal of Science Education, 24(9), 919-940. doi: $10.1080 / 09500690110098903$

Kim, E. \& Kwon, H. (2016). Phenomenological study on the elementary students' experience participating in the science fair. Journal of the Korean Association for Science Education, 36(1), 113-123. doi: 10.14697/jkase.2016.36.1.0113

Koballa, T. R. \& Glynn, S. M. (2007). Attitudinal and motivational constructs in science learning. In S. K. Abell \& N. G. Lederman (Eds.), Handbook of research on science education (pp. 75-102). Mahwah, NJ: Lawrence Erlbaum.

Korkmaz, H. (2004, September). The images of the scientist through the eyes of the Turkish children. Paper presented at the Panhandle Science and Mathematics Conference, Canyon, Texas, USA.

Korkmaz, H. (2012). Making science fair: How can we achieve equal opportunity for all students in science? Procedia - Social and Behavioral Sciences, 46, 3078-3082. doi:10.1016/j.sbspro.2012.06.014

Laçin-Şimşek, C. (2011). Okul dışı öğrenme ortamları ve fen eğitimi. C. Laçin-Şimşek (Ed.), Fen Öğretiminde Okul Dışı Öğrenme Ortamları (ss. 124). Ankara: Pegem Akademi.

Maguth, B. M. \& Yamaguchi, M. (2010). Beyond the surface: A guide to substantive World fairs in the social studies. The Social Studies, 101(2), 75-79. doi: 10.1080/00377990903284062

MEB (2005). ilköğretim Fen ve Teknoloji Dersi Öğretim Programı. Ankara: Milli Eğitim Basımevi.

MEB (2013). Ilköğretim Kurumları Fen Bilimleri Dersi Öğretim Programı. Ankara: Milli Eğitim Basımevi.

MEB (2017). Fen Bilimleri Dersi Öğretim Programı. Ankara: Milli Eğitim Basımevi.

MEB (2018). Fen Bilimleri Dersi Öğretim Programı. Ankara: Milli Eğitim Basımevi. http://mufredat.meb.gov.tr/ProgramDetay.aspx?PID=325 adresinden erişilmiştir.

National Research Council. (2009). Learning science in informal environments: People, places, and pursuits. The National Academies Press: Washington, D.C.

Ndlovu, M. (2013, November). Science fair learners' evaluation of their experience of scientific investigations in the classroom and during their project work. Paper presented at the ICERI 2013 Conference, Seville, Spain.

Ngcoza, K. M., Sewry, J., Chikunda, C. \& Kahenge, W. (2016). Stakeholders' perceptions of participation in science expos: A South African case study. African Journal of Research in Mathematics, Science and Technology Education, 20(2), 189-199. doi: 10.1080/18117295.2016.1192238

Osborne, J. F. \& Dillon, J. (2008). Science education in Europe. London: Nuffield Foundation.

Özbaş, S. (2016). Lise öğrencilerinin biyoloji dersine yönelik tutumları. Turkish Studies, 11(9), 659-668. doi: 10.7827/TurkishStudies.9371

Pallant, J. (2013). SPSS survival manual. Open University Press, Mc-Graw Hill Education: Chicago.

Potvin, P. \& Hasni, A. (2014). Interest, motivation and attitude towards science and technology at K-12 levels: A systematic review of 12 years of educational research. Studies in Science Education, 50(1), 85-129. doi: 10.1080/03057267.2014.881626

Schmidt, K. M. (2014). Science fairs and science olympiad: Influence on student science inquiry learning and attitudes toward STEM careers and coursework. Unpublished doctoral dissertation, Northern Illinois University, Illinois, USA.

Schmidt, K. M. \& Kelter, P. (2017). Science fairs: A qualitative study of their impact on student science inquiry learning and attitudes towards STEM. Science Educator, 25(2), 126-132.

Sert-Çıbık, A. (2009). Proje tabanlı öğrenme yaklaşımının öğrencilerin fen bilgisi dersine yönelik tutumlarına etkisi. ilköğretim Online, 8(1), 36-47.

Sorge, C., Newsom, H. E., \& Hagerty, J. J. (2000). Fun is not enough: Attitudes of Hispanic middle school students toward science and scientists. Hispanic Journal of Behavioral Sciences, 22(3), 332-345. doi: 10.1177/0739986300223004

Şişman, M., Acat, M. B., Aypay, A. \& Karadağ, E. (2011). TIMSS 2007 Ulusal Matematik ve Fen Raporu 8. Sınıflar. Ankara: Hermes Ofset.

Tabachnick, B. G. \& Fidell, L. S. (2013). Using multivariate statistics (6th ed.). Boston: Pearson

Tortop, H. S. (2014). Examining of the predictors of pre-service teachers' perceptions of the quality of the science fair projects in Turkey. Necatibey Eğitim Fakültesi Elektronik Fen ve Matematik Eğitimi Dergisi (EFMED), 8(1), 31-44. 
Tosun, C. \& Genç, M. (2015). Adaptation of science attitude scale developed for elementary school students to turkish: Validaty and reliability study. Elementary Education Online, 14(3), 946-960. doi: 10.17051/io.2015.08787

Wang, T. L. \& Berlin, D. (2010). Construction and validation of an instrument to measure Taiwanese elementary students' attitudes toward their science class. International Journal of Science Education, 32(18), 2413-2428. doi:10.1080/09500690903431561

Yaşar, Ş. \& Baker, D. (2003, March). The impact of involvement in a science fair on seventh grade students. Paper presented at the Annual Meeting of the National Association for Research in Science Teaching, Philadelphia, PA. Retrieved from http://eric.ed.gov/?id=ED478905

Yaşar, Ş. \& Anagün, Ş. S. (2008). İlköğretim beşinci sınıf fen ve teknoloji dersi tutum ölçeğinin geçerlik ve güvenirlik çalışmaları. Anadolu Üniversitesi Sosyal Bilimler Dergisi, 8(2), 223-236.

Yıldııım, A., Şekercioğlu, A. \& Yıldırır, H. E. (2018). Fen bilimleri dersi 8. sınıf öğrencilerinin "kimyasal bağlar" konusundaki başarılarına ve derse yönelik tutumlarına drama destekli öğretimin etkisi. Balıkesir Üniversitesi Fen Bilimleri Enstitüsü Dergisi, 20(2), 255-272. doi: $10.25092 /$ baunfbed.428983

Yıldııım, A. \& Şimşek, H. (2018). Sosyal bilimlerde nitel araştırma yöntemleri (11. Baskı). Ankara: Seçkin Yayınevi.

Yıldııı, H. i. \& Kansız, F. (2017). Ortaokul öğrencilerinin fen dersine yönelik tutum düzeylerinin bazı değişkenler açısından incelenmesi -1. The Journal of Academic Social Science Studies, 60, 17-40. doi: 10.9761/JASSS7273x?ID=7273

Young, T. E. (2000, March-April). Science fair projects bring it all together: Collaboration, information literacy, and public relations (pp. 6-8). Book report. 